\title{
Geoliteracy i ungdomsskolen: Hvordan legger en ungdomsskolelærer til rette for lesing av grafiske representasjoner i geografi?
}

\author{
Hanne Egenæs Staurseth* \\ Nasjonalt senter for leseopplering og leseforsking, Universitetet $i$ Stavanger
}

\begin{abstract}
Sammendrag
I senere år har både norsk og internasjonal leseforskning vektlagt og operasjonalisert fagpersonens tenke- og væremåter for å finne fagrelevante tekstpraksiser. Et skolefag som har fått lite oppmerksomhet, er geografi. Det er vanskelig å tenke seg geografifaget uten grafiske representasjoner som kart og diagram. Denne artikkelen utforsker dette underbeskrevede fagdidaktiske området gjennom en case-studie med følgende spørsmål: Hvordan legger en ungdomsskolelærer til rette for lesing av grafiske representasjoner i geografi i et gitt emne? Spørsmålet utforskes med empiri fra to skoletimer der åttendeklasseelever har sine første tilnærminger til de grafiske representasjonene klimasonekart og klimadiagram. Artikkelen henter begrep fra sosialsemiotikkens visuelle grammatikk og fra leseopplæringsteori for å synliggjøre utfordringer elevene kan ha med tekstene, samt hvordan lærer tilrettelegger for lesing av dem. Utdragene fra klasserommet viser at det både er faglige og tekstlige utfordringer ved å bruke grafiske representasjoner, og at læreren spiller en vesentlig rolle i forståelsen av disse ved å gi eksplisitt instruksjon i spesialiserte måter å lese representasjonene på gjennom deiktisk modellering, oppgavedesign som utforsker tekstene og reflekterende spørsmål.
\end{abstract}

Nøkkelord: Fagspesifikk literacy; literacydidaktikk; lesing i geografi; grafiske representasjoner; ungdomsskolen

\begin{abstract}
Norwegian and international literacy research have in recent years emphasized and operationalized the subject expert's conduction of and way of thinking in disciplines in search of adequate disciplinary literacy practices. One school subject that has received little research attention is geography. It is difficult to imagine geography without graphical representations such as maps and diagrams. This article explores this underdescribed field of research through a case-study with the following question: How does a lower secondary school teacher facilitate students' reading of graphical representations in geography in a given topic area? The question is explored through empirical data from two lessons during which one class of eighth grade students have their initial approaches to the graphical representations climate zone maps and climate diagrams. The article applies concepts from
\end{abstract}

\footnotetext{
^Correspondence to: Hanne Egenæs Staurseth, Nasjonalt senter for leseopplæring og leseforsking, Universitetet i Stavanger, 4036 Stavanger, Norge. Email: hanne.e.staurseth@uis.no
} 
the social semiotics' grammar of visual design and literacy theories to make apparent students' challenges with graphical representations and how the teacher facilitates the reading of such texts. The article demonstrates that there are both disciplinary and textual challenges relating to the use of graphical representations, and emphasizes the role of the teacher in students' reading of such representations by giving explicit instruction in specialized ways to read the representations through deictic modeling, task designs that explores the texts, and reflective questions.

Key words: Disciplinary literacy; literacy didactics; reading in geography; graphical representations; lower secondary school

Received: May, 2017; Accepted: October, 2017; Published: June, 2018

\section{Introduksjon}

Geografi er et visuelt og tekstrikt fag hvor grafiske representasjoner som kart, statistikk, grafer og tabeller har en sentral plass. Det finnes spesialiserte måter å lese slike grafiske representasjoner i geografifaget, som å kunne se hvordan deler hører til helheter i et kart eller hvordan et element påvirker et annet i et diagram (van Leeuwen \& Humphrey, 1996). Å lese og skrive geografifaglige tekster forstår jeg som geoliteracy i denne artikkelen.

I Norge har det vært stor avstand mellom forskningsfaget og skolefaget geografi. Vi vet lite om geografiundervisning, hva elevene lærer og hvilke utfordringer og behov geografiundervisningen, særlig i grunnskolen, står overfor. (Eikli, 2013). I grunnskolen er geografi en del av skolefaget samfunnsfag. Beskrivelsen Kunnskapsløftet gir av lesing i samfunnsfag, nevner grafiske representasjoner eksplisitt: Elevene skal kunne bruke, sammenligne og kritisk vurdere informasjon fra mange og ulike kilder - også fra «bilete, film, teikningar, grafar, tabellar og kart» (Udir, 2013). Mens læreplanen legger føringene, er det lærerne som må lage undervisningsforløp hvor tekstene tas i bruk, og elevene som skal bruke dem. Å skape mening av grafiske representasjoner krever en annen lesekompetanse enn å skape mening fra verbalspråklig tekst. Anne Løvland (2011) diskuterer sammenhengen mellom multimodalitet og læring i lys av klasseromsobservasjoner, elevintervju og elev- og læringstekster på mellomtrinnet i norsk skole. Hun finner at læringspotensialet kan være underutnyttet fordi elevene ikke bruker tjenlige lesestrategier og fordi lærerne designer aktiviteter som ikke utnytter multimodaliteten i visuelle tekster.

Med denne bakgrunnen formuleres følgende forskningsspørsmål: Hvordan legger en ungdomsskolelærer til rette for lesing av grafiske representasjoner i geografi i et gitt emne? Spørsmålet undersøkes gjennom en case-studie der en lærer og hans åttendeklasse jobber med geografifaglig klimakunnskap representert grafisk gjennom klimasonekart og klimadiagram.

\section{Teoretisk forankring}

Literacy som sosial praksis

Studien bygger på en forståelse av literacy som sosial praksis. Fordi tekstbruk avhenger av situasjon og kulturell forankring, brukes ofte sosialantropologiske metoder for å 
beskrive situasjoner hvor lesing og skriving har en naturlig plass. Konkrete teksthendelser ses som observerbare uttrykk for tekstpraksiser (Barton \& Hamilton, 1998; Heath, 1983; Scribner \& Cole, 1973; Street, 1984).

I skolens leseopplæring blir både skolens og fagets tradisjoner bakteppe for leseaktiviteten. Overføring av fagkunnskap framstilt som fakta kaller Wade \& Moje (2000) overføringsmodellen. Vi vet at dette, samt memorisering og reproduksjon av tekst, tradisjonelt har veid tungt i undervisning (Blikstad-Balas, 2013; Skjelbred, 2006; Säljö, 2010). I senere år har derimot det å vektlegge og operasjonalisere fagpersoners tenke- og væremåter for å finne fagrelevante tekstpraksiser fått mye oppmerksomhet (Kleve \& Penne, 2012; Skaftun, Solheim \& Uppstad, 2014; Skjelbred \& Aamotsbakken, 2010; Traavik, Hallås \& Ørvig, 2009). Kjernen i slik fagspesifikk literacy er å gjøre klart hvordan en får tilgang til samt produserer kunnskap i ulike disipliner slik at elevene ikke bare gis tilgang til et spesifikt kunnskapsfelt, men òg ser hvordan ideer, kunnskap og begrep konstrueres og medieres (Moje, 2015). Det å bli lesekyndig i et fag innebærer å bli fortrolig med tekstkulturer, lesemåter og skriftpraksiser i faget. I fagspesifikk literacy blir det derfor viktig å beskrive unik bruk av tekst og språk innenfor fagområder: Studier innen funksjonell lingvistikk har vist hvordan disipliner innehar ulike sjangre med ulike grammatiske trekk (Schleppegrell, 2004).Videre har studier utforsket hvordan eksperter i ulike felt har ulike tekstpraksiser (Shanahan, Shanahan \& Misischia, 2011), forskjellen i strategibruk og tenking mellom noviser og eksperter (Alexander, 2003), og skapt teksthendelser i klasserommet som minner om ekspertenes praksis (Reisman, 2012). Både i norsk og internasjonal kontekst har større fag som morsmålsfaget (Gourvennec, 2016; Hoel \& Håland, 2016; Rainey, 2017) og naturfag (Knain, 2014; Pearson, Moje \& Greenleaf, 2010; Sørvik \& Mork, 2015) fått størst oppmerksomhet. Innenfor samfunnsfagene har fokus vært på historie (Hoem \& Staurseth, 2014; Wineburg, 2001).

\section{Hvilke tekstlige utfordringer finnes når en skal lese grafiske representasjoner?}

Grafiske representasjoner krever en annen lesekompetanse enn verbalspråklig tekst. Mens ord i verbalspråklig tekst er organisert lineært og bygger mening sekvensielt, er grafiske representasjoner visuelle uttrykk med romlig oppbygging. Skal en undervise i og med grafiske representasjoner, er det avgjørende å forstå hvordan de er konstruert og hvilke aspekter som kan skape utfordringer. Til dette kan Gunther Kress og Theo van Leeuwens (2006) visuelle grammatikk gi begrep. De deler semiotisk mening inn i representasjon, komposisjon og interaksjon.

Representasjon handler om hvordan fremstillingen representerer verden. Her skisseres to hovedmønstre:

1. Narrative representasjoner fremstiller utfoldelsen av handlinger, hendelser eller endringsprosesser gjennom en vektor, en visuell linje. Et geografisk teksteksempel er klimadiagram, som viser utfoldelsen av gjennomsnittsværet på et gitt sted med temperaturendringen framstilt gjennom to linjer (se figur 6, s. 94). 
2. Konseptuelle representasjoner definerer, analyserer eller klassifiserer det avbildede til generelle, stabile eller tidløse essenser, som å tilhøre en kategori eller ha visse komponenter. Et geografisk teksteksempel er klimasonekart, som klassifiserer jorda i klimasoner (se figur 1$){ }^{1}$

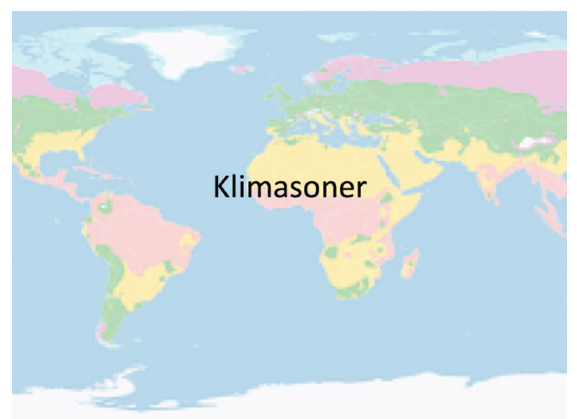

Figur 1. Klimasonekart: En konseptuell representasjon.

Begge teksteksemplene fremstiller klimamønster, men mens klimadiagrammet viser en narrativ endring ett sted, viser klimasonekartet stabile kategorier over hele jorda.

Komposisjon handler om hvordan deler av representasjonen kobles til et gienkjennelig hele gjennom tre kategorier:

1. Informasjonsverdi: Plasseringen i komposisjonen gir elementene rolle. Her finnes konvensjoner, både generelle og spesifikke knyttet til konkrete sjangre og tekstpraksiser. Eksempelvis gjør vestlig leseretning det vanlig å plassere kjent informasjon til venstre og ny, problematisk eller diskutabel informasjon til høyre.

2. Innramming: Element kan presenteres som separerte eller sammenhørende. Rammer, tomrom eller kontraster separerer, mens likheter i farge og form, vektorer eller fraværet av rammer binder sammen.

3. Framtredende element: Noen element er mer iøynefallende enn andre, eksempelvis grunnet størrelse, farger og kontraster.

Interaksjon handler om hvordan forholdet mellom leser og tekstuttrykk er konstruert giennom synsvinkel, avstand til motivet eller ressurser som tilbyr eller krever noe av mottaker. I grafiske representasjoner er modalitet sentralt. I denne sammenhengen kan modalitet oversettes med virkelighetsverdi og beskriver hvor reliabel en tekst er innenfor hvilken virkelighetsdefinisjon den blir målt mot (Kress og van Leeuwen, 2006).

1. Innenfor naturalistisk modalitet er det høyere virkelighetsverdi jo større samsvar avbildningen har til det reelle objektet. Et foto av jordkloden (figur 2) presenterer

\footnotetext{
${ }^{1}$ Figur 1 og 2 er teksteksempler fra klasserommet som studeres i denne artikkelen. Bildene er fra PowerPoint brukt av lærer i første time i emnet "Natur vs. samfunn".
} 


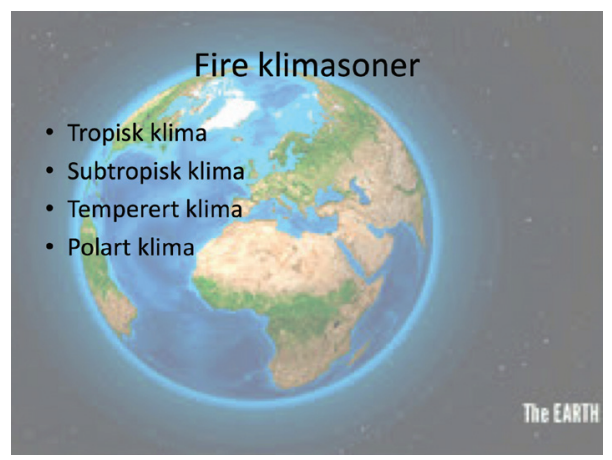

Figur 2. Satelittbilde av jordkloden i naturalistisk modalitet.

jorda «slik den ser ut». De fleste vil se den som en reliabel representasjon, selv om de færreste har sett jorda fra denne synsvinkelen.

2. Innenfor vitenskapelig modalitet abstraheres fenomen. I klimasonekartet (figur 1) er jordas former abstrahert til en skjematisk profil med konvensjoner og koder. Klimasonekartet har en annen reliabilitet enn satellittfotoet og framstiller systematiske klimamønstre mer adekvat enn satelittfotoet kan.

\section{Hvordan skal elever lære å lese i geografifaget i skolen?}

Det finnes få studier på fagspesifikke tekstpraksiser i geografi. En sammenligning Johnson, Watson, Delahunty, McSwiggen \& Smith (2011) gjør av ekspertpraksiser i matematikk og geografi gir likevel innblikk i hvordan én geograf vurderer sammenhengen mellom faglige forståelser, tenkemåter og tekstbruk. Geografen mener kjernen i geografi er å beskrive mønstre på jorda og prosessene som skaper disse. Numeriske, symbolske og grafiske representasjoner blir sentrale fordi de muliggjør fremstilling av mønstre og prosesser. Faget drives framover av spesifikke, utforskende spørsmål som sammenstiller element fra naturgeografiske prosesser som temperatur, nedbør og forholdet til jordas akse, og samfunnsgeografisk interaksjon mellom menneskelig aktivitet og natursystemer. I identifiseringen av mønstre anser geografen brede basiskunnskaper, eksempelvis fra fagene historie, økonomi og naturvitenskapene, som gunstig. For å få god bakgrunnskunnskap om stedet hun utforsker, bruker hun sekundære kilder fra tidsskrift, fysiske data samt mer populistiske tekster i tillegg til grafiske representasjoner.

Grafiske representasjoner, som kart og diagram, kan altså uttrykke resultatet av en geografisk utforsking og er en sentral måte å representere kjernegeografisk kunnskap. Sjangeren vil gi elever tilgang til viktig geografifaglig kunnskap. Et avgjørende spørsmål blir hvordan en kan tilrettelegge for at noviser, med begynnende kjennskap til faget, skal kunne se tekstene de bruker i sammenheng med hvordan ideer, kunnskap og begrep er konstruert og mediert i faget. Gee (2002) argumenterer for å la elevene simulere hvordan mer erfarne fagfolk situerer mening i og om domenet. 


\section{Hanne Egences Staurseth}

Siden det kan være utfordrende å oppdage hvilke element en bør gi oppmerksomhet, anbefaler Gee (2002) at en mer erfaren tekstbruker modellerer prototyper og eksplisitt viser hvilke element som bærer vesentlig informasjon, for deretter å la elevene selv produsere faglige ytringer som de får tilbakemeldinger på. Gjennom å simulere spesialiserte lesemåter får elevene tilgang til materialet, diskurser og tenkemåter i faget, noe Gee (2002) mener kan gjøre dem forberedt til selv å ta del i fagkulturen. Også metastudier på elevers leseutvikling generelt peker i lignende retning. I Biancarosa \& Snow (2006) framheves blant annet å undervise eksplisitt $i$ leseforståelse gjennom å gi innføring i og modellere lesestrategier og metakognisjon, å legge vekt på fagets spesifikke lese- og skrivepraksiser, la elevene samhandle om tekst, ikke bare om faginnhold, og å tilby elevene et mangfold av tekster. Det ses som viktig å gi mye støtte mens elevene øver på nye ferdigheter, sakte redusere denne for å styrke eierskap og selvstendighet, samt å la elevene bruke strategiene i ulike kontekster, fagområder og sjangre.

\section{Forskningsdesign}

Denne studien tar utgangspunkt i et ønske om å undersøke dynamikken mellom tekst, fag og undervisning når grafiske representasjoner brukes i læringssituasjoner. Studier i fagspesifikk literacy s er ofte til e kspertpraksiser, m en d et e r i utfoldelsen i klasserommet, i skjæringspunktene mellom de mange faglige, tekstlige og pedagogiske hensynene, at lærere må navigere. For å innhente detaljert, kontekstavhengig og holistisk viten (Flyvbjerg, 1991), avgrenses studien til én lærer, hans åttendeklasse i samfunnsfag med 27 elever og geografiemnet "Natur vs. samfunn" på 18 undervisningstimer. Studien er en deskriptiv case-studie med følgende spørsmål: Hvordan legger en ungdomsskolelerer til rette for lesing av grafiske representasjoner $i$ geografi $i$ et gitt emne?

Jeg kontaktet en samfunnsfaglærer uten fordypning i literacy, men som jeg visste var erfaren, faglig trygg og dyktig i å involvere elevene i undervisningen. Læreren fikk vite at studieobjektet var grafiske representasjoner. Han foreslo geografiemnet "Natur vs. samfunn”, om hvordan natur og samfunn kan være på kollisjonskurs angående klima. Det var læreren som planla og gjennomførte undervisningen. Fordi emner utformes som helheter som introduseres, arbeides med og munner ut i vurderingssituasjoner, så jeg det som viktig å følge hele emnet. Jeg var deltakende observatør i samfunnsfagtimene i syv uker. Forankret i et teoretisk rammeverk som ser teksthendelser som konkrete, observerbare uttrykk for tekstpraksiser, beskrev og dokumenterte jeg leseog skriveaktiviteter gjennom feltnotat, fotografier og lydopptak av timene. I særs visuelle hendelser, som lærers tavlevisualiseringer eller tekstforklaringer, ble det tatt videoopptak. Jeg transkriberte og anonymiserte opptakene.

Første sortering av materialet viste at særlig to grafiske representasjoner, klimasonekart og klimadiagram, gikk igjen i emnet. Denne artikkelen presenterer samtaler 
fra elevenes første tilnærminger til disse representasjonene. Utdragene er valgt fordi de, som de første leser-tekst-møtene, tydelig illustrerer utfordringer elevlesere på ungdomsskolen kan ha med geografifagets tekster. For å få fram detaljer om hvordan læreren tilrettelegger for lesing av klimasonekart og klimadiagram, analyserte jeg utdragene gjennom Kress og van Leeuwens kategorier representasjon, komposisjon og interaksjon, samt eksplisitt leseforståelsesinstruksjon, som simulering (Gee, 2002), modellering og metakognisjon (Biancarosa \& Snow, 2006), og fagspesifikk tekstbruk, som å identifisere mønster og sammenstille element (Johnson et al., 2011). Studien søker ikke å generalisere literacy-praksiser i ungdomsskoleklasserom, men å gi næring til en diskusjon om hvordan lærere kan tilrettelegge for lesing av grafiske representasjoner i geografifaget.

\section{Hvordan legger en ungdomsskolelærer til rette for lesing av grafiske representasjoner $i$ geografi i et gitt emne?}

Vi skal se på to undervisningssekvenser. Først presenteres et utdrag der elevene skal forenkle klimasonekart, så analyseres tekstuttrykkets utfordringer og lærerens modellering. Deretter gjøres tilsvarende med et utdrag hvor elevene skal lære å lese klimadiagram.

\section{Eksempel 1: Hvordan legger lærer til rette for lesing av klimasonekart?}

Emnet «Natur vs. samfunn» handler om klima. Læreren introduserer emnet ved å påpeke at elevene kjenner steder med likt og ulikt klima. Første timen foregikk som en klasseromssamtale, strukturert etter en PowerPoint. På lysbilde av jordkloden (figur 2) viste læreren at noen områder er gule og tørre, andre grønne og frodige. Ved hjelp av klimasonekart (figur 1) presiserte han hvordan klimavariasjonen er systematisk. Jorda kan deles i fire klimasoner: Polar, temperert, subtropisk og tropisk. Han visualiserte på tavla hvordan klimavariasjonen knyttes til sola og jordas rotasjon. Deretter gjennomgikk de klimasonenes kjennetegn.

Læreren ønsker nå å repetere kunnskapen ved å la elevene tegne de fire sonene på blanke kart. Han ber dem hente atlas og finne temakart:

Og så vil jeg rett og slett at dere skal tegne det her av, på et verdenskart som dere får ut. Fint og så presist som dere kan. Jeg kommer til å ta ut de fargene [klassens fargestifter], og så kan dere bruke de eller deres egne, så bruker vi ikke tid på det i starten.

Mens elevene setter seg sammen og finner klimakartet (figur 3), deler læreren ut blanke verdenskart. Elevene jobber i par eller smågrupper med atlaset foran seg. Noen starter raskt å fargelegge. Andre diskuterer hvilke farger de skal velge. Læreren har tenkt at elevene skal forenkle atlaskartet til fire klimasoner. Få utfører oppgaven slik. Flesteparten tegner av kartet. Et mindretall velger fire kategorier, noen utfra fargene de har valgt. 


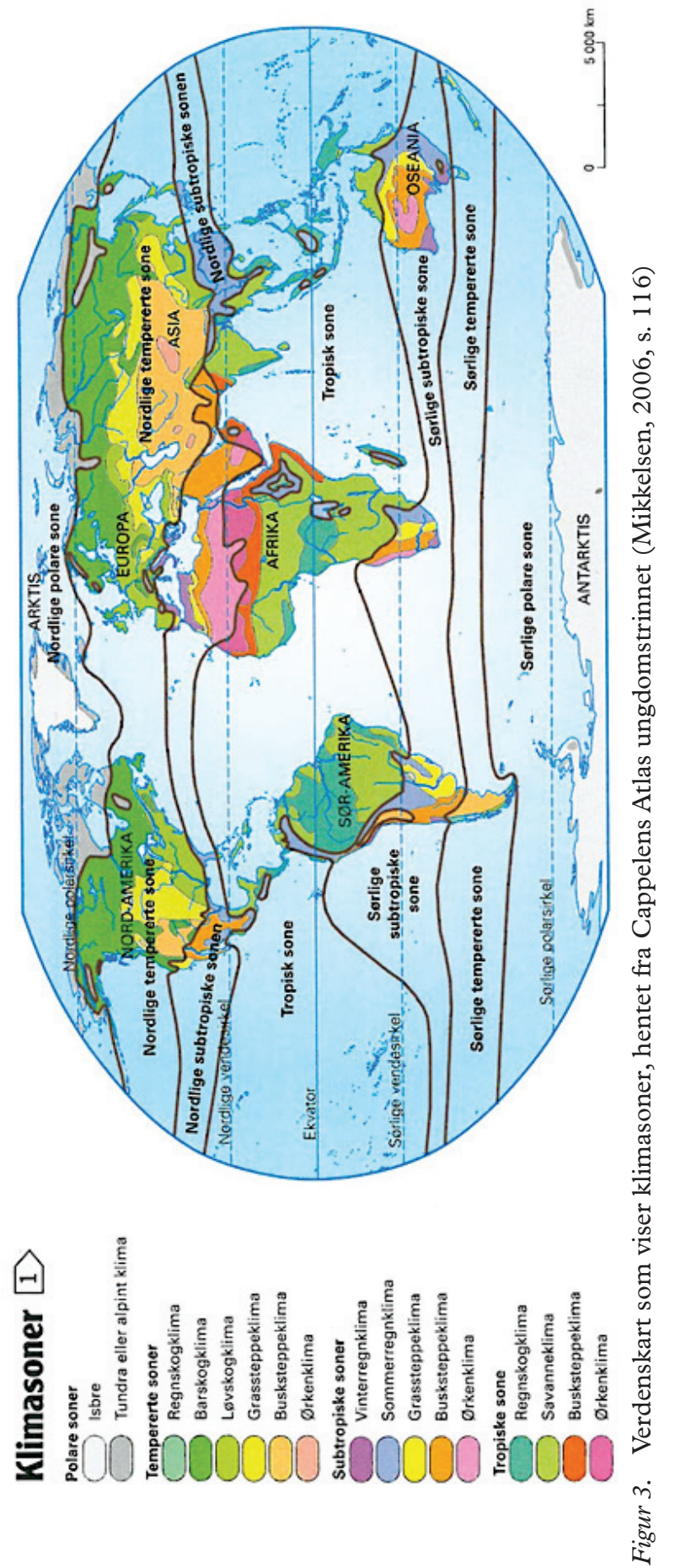


Den første som sier seg ferdig, er Martin. Læreren studerer tegningen hans (figur 4), som viser fargekoder for:

- hav/vann (blå)

- skog/temperert (grønn)

- Subtropisk (gul)

- busksteppeklima (oransje)

Kategoriene er en blanding av overkategorier (temperert, subtropisk), underkategorier (busksteppeklima) og kategorier som ikke finnes i atlaset (skog, hav/vann). Læreren spør: "Hva er hva da?» Martin svarer ikke. "Hvilke soner var det du skulle tegne inn der? Hvordan har du valgt ut de du har valgt nå?» Martin ser på ham, så på tegningen. Læreren peker på Martins koder: «Her har du busksteppeklima.» Deretter peker han i atlaset på kategori busksteppeklima under subtropisk: «Den har du med. Har du med de andre her da? Grassteppeklima?» Martin svarer: «Det er på grunn av subtropisk.» Læreren utfordrer:

Lærer: Men hva, hvilke kategorier bruker du da? Bruker du de som er hoved-/

Martin: Hmmmmm.

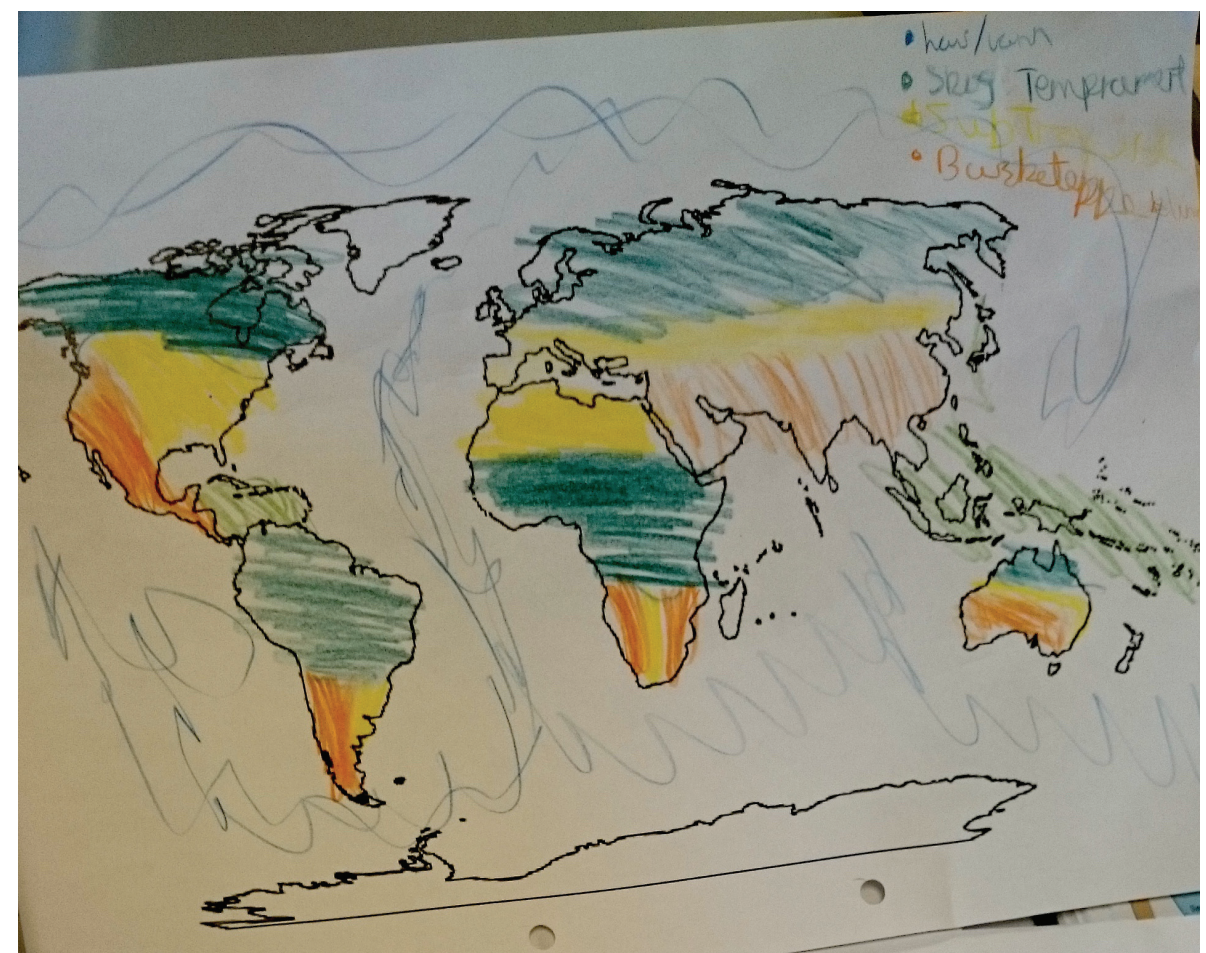

Figur 4. Martins første klimakart - strukturert etter farger. 
Lærer: /-kategorier? ...

Martin: Ja

Lærer: ... eller har du bare valgt ut noen av de små?

Martin: Jeg bruker hoved-eeeehh-kategorier ...

Lærer: Hvordan kom den oransje med da?

Martin: (.) Jo, den skal være gul.

Lærer: Klarer du å se tydelig på kartet ditt hvor polarsonen er, den tempererte sonen, den subtropiske og den tropiske?

Siden det er vanskelig å tydeliggjøre de fire kategoriene i Martins kart, får han et nytt. Læreren forklarer: "Poenget her var å få fram de fire hovedsonene så presist som mulig.» Læreren ber Martin vise hvordan han finner hovedkategoriene i nord og sør, og lar ham tegne på nytt. Martin tegner nå de buktede linjene og skriver navn på sonene i kartet (figur 5).

Langt flere enn Martin blander kategoriene. En av dem er Jakob. Læreren spør: «Men, Jakob, hva er det du skal vise da?» «Klima!» smiler Jakob. «Klimasoner, okei. De fire, sant», retter læreren. «Hvor finner du de på kartet?» "På kartet? Temperert, det er grønn. Og gul. Og grønngul. Eller litt sånn mørkegul» Læreren utfordrer: «Men her er det jo to grønne?» Jakob konstaterer: «Det er jo fordi det er samme.» Han peker på kodene: «Regnskogsklima og regnskogsklima.» Læreren viser til

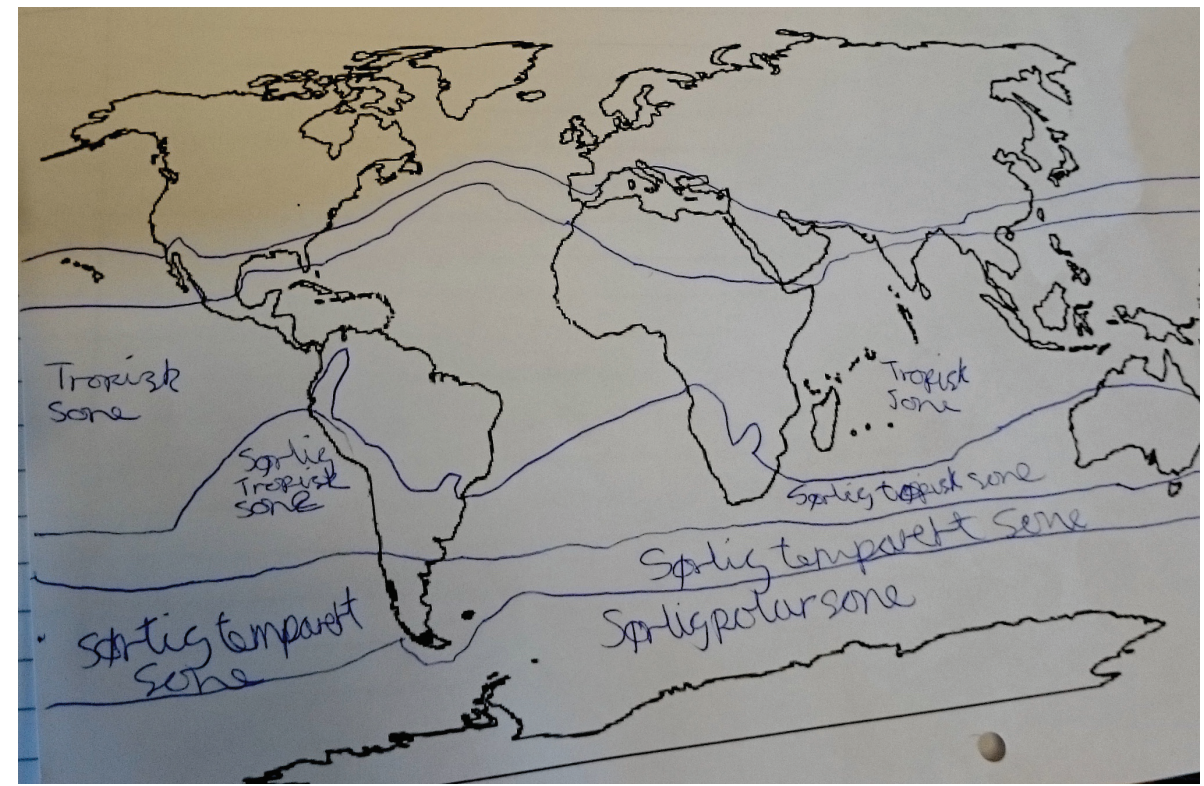

Figur 5. Martins andre klimakart - strukturert etter streker. 
hovedkategoriene: «Men de ligger under noen overskrifter her, ser du det?» Han presiserer spørsmålet: «Hvordan finner du de fire der (peker på overskriftene som angir de fire klimasonene)?»

\section{En utfordrende oppgave}

Læreren ber elevene forenkle et komplekst klimakart (figur 3) til et enklere (lignende figur 1). Oppgaven var planlagt som en kjapp aktivitet for å repetere på en visuell og elevaktiv måte hvordan klimasonene strekker seg som belter over jorda. Etter hvert som tegningene tar form, ser læreren at elevene ikke forstår intensjonen hans, og aktiviteten tar hele skoletimen. Hvorfor er oppgaven så utfordrende for elevene? Vi ser at begge guttene, og flere med dem, setter likhetstegn mellom klimasonene og fargene som representerer kategoriene. De har vanskeligheter med å differensiere klimatyper og klimasoner. Jakob avslører i tillegg en annen utfordring: Flere klimatyper finnes i ulike klimasoner, eksempelvis er busksteppeklima underkategori i tre av klimasonene. Klimasonekartet i atlaset er ikke bare mer komplekst enn klimasonekartet læreren vil de skal tegne, det er også bygget med en annen "grammatikk». I det følgende diskuteres tekstuttrykkets utfordringer, hva elevene finner utfordrende og hvordan læreren modellerer. Kress og van Leeuwens (2006) kategorier, representasjon, komposisjon og interaksjon strukturerer analysen.

\section{Representasjon}

Klimasonekartet deler jorda i klimasoner og kan plasseres som en konseptuell representasjon. Kartet hører videre til underkategori analytisk struktur, som involverer seleksjon: Noen egenskaper representeres som essensielle, andre utelates eller fremstilles som mindre viktige. I figur 3 representeres konseptet klimasoner gjennom hovedkategorier (klimasoner) og underkategorier (klimatyper). Kartet er en type analytisk struktur der delene er gjensidig ekskluderende; hvert sted tilhører en klimatype som igjen tilhører en klimasone. Likevel finnes mange klimatyper, som regnskogklima og busksteppeklima, i flere klimasoner.

Det virker ikke som Martin og Jakob forstår representasjonen og strukturen kartet har. Martin har tegnet hav/vann, skog/temperert, subtropisk og busksteppeklima. Blandingen av klimatyper, klimasoner og hav/vann gjør ikke kategoriene gjensidig ekskluderende. Når læreren spør hvordan han valgte kategoriene, har Martin vanskelig for å svare. Blått hav er konvensjonelt i kart, og Martin har sannsynligvis sett mange slike kart. Også i figur 3 er havet blått, men det finnes ingen kode for hav/ vann. I et klimasonekart, en konseptuell analytisk struktur, er det konseptet klimasoner som fremstilles analytisk. Hav er ingen klimasone, og dermed ingen kategori. Martin spiller således på en annen fagspesifikk tekstpraksis når han henter element fra et vanlig kart, men som kategori innenfor det domenespesifikke klimasonekartet gir ikke hav/vann mening.

Elevene i $8 b$ er generelt opptatt av hvilke farger de skal velge. Begge guttene nevner farger når læreren spør hvordan de ulike kategoriene kom med: «Jo, den skal 
være gul» (Martin), "eller litt sånn mørkegul» (Jakob). Det virker ikke som elevene forstår fargenes betydning i kartet, at seleksjonen og sorteringen handler om hva som er essensielt i denne type kart. Seleksjonen er svært faglig. Når læreren ber dem tegne med fire farger, må elevene foreta en ny seleksjon. Uten modellering i starten av timen (jf. Biancarosa og Snow, 2006; Gee, 2002), løser de oppgaven som en ren fargeleggingsoppgave med fritt fargevalg. Mange elever tegner nøyaktig, men direkte av kartet med flere enn fire farger. Problemet hos Martin og Jakob er at de velger fire kategorier uten å forstå bakgrunnen for seleksjonen. Kartene får dermed ikke helhet-del-strukturen en analytisk struktur krever. Læreren starter med å spørre guttene hvilke soner de skulle tegne inn (Martin) og hva det var de skulle vise (Jakob). Å få elevene til å sette ord på hvordan de tenker, gir dem et metakognitivt blikk på egen tekstforståelse (jf. Biancarosa \& Snow, 2006). Det gir også læreren et inntrykk av tekstforståelsen deres, som han kan tilpasse veiledningen etter. Måten spørsmålene er uttrykt på, antyder likevel at han tar det for gitt at elevene skjønner tekstens representasjon, og han griper ikke fatt i det upresise svaret «Klima!» som Jakob gir.

\section{Komposisjon}

Klimasonekartet (figur 3) har en venstre-høyre-struktur, ifølge sosialsemiotikken en struktur der kjent informasjon oftest står til venstre. I klimasonekartet er det faglige, og for elevene ukjente, begrep som står der. Under overskriften «Klimasoner» (helheten) sorteres klimatypene (delene), kodet med farger, under navngitte klimasoner. Høyre tekstdel er verdenskartet hvor klimatypene representeres med farger og klimasonene med svart skrift og tverrgående linjer. Kartet presenteres som egen tekstdel, innrammet av en tynn blå strek, separert fra kodene. Fargene binder likevel de to delene sammen. Kodene til venstre forklarer kartet til høyre. Kart og koder må derfor samleses.

Klimatypene går i flere tilfeller igjen i ulike klimasoner. Ser vi nøyere på hvilke farger ulike klimatyper har, ser vi at grønt markerer skog, gult steppeklima, rosa ørken og blå/lilla regnklima. At Martin setter sammen skog og temperert til én kategori, kan trolig forklares med at tre av seks klimatyper i temperert sone er skogtyper: Regnskogklima, barskogklima og løvskogklima, alle representert med ulike grønnfarger. Også regnskogklima og savanneklima innenfor tropisk sone er grønne. Det Martin har farget grønt, samsvarer med områdene disse fem grønnfargene dekker i kartet. Den tredje kategorien hans er subtropisk sone, fargekodet gul. Martins gule felt stemmer bedre med de gule flekkene i kartet, klimatypen grassteppeklima som finnes både i temperert og i subtropisk sone, enn sammenslåingen av de fem klimatypene som utgjør subtropisk sone. Martins siste kategori er busksteppeklima. I atlaset er busksteppeklima underkategori i både temperert, subtropisk og tropisk sone. Områdene Martin har fargelagt, ligner de oransje fargene i kartet. Av kartet hans (figur 4) ser det derfor ut som Martin har fremstilt kartet til høyre i figur 3 uten å gå veien om kodene til venstre. 
At elevene er opptatt av fargene, handler trolig om at fargene er iøynefallende. Det er derimot i listen med overskrifter og fargekoder at hierarkiet mellom klimasoner og klimatyper kommer tydeligst frem. Læreren peker mot listen når han stiller Martin og Jakob spørsmål og viser at det finnes over- og underkategorier, før han spør dem hvordan de kan finne igjen overskriftene på kartet. Når han eksplisitt modellerer (Biancarosa \& Snow, 2006) hvordan en samleser kodene og kartet (Johnson et al., 2011), har guttene ingen problem med å bruke strekene eller finne sonene som er skrevet på kartet.

\section{Interaksjon}

Ifølge Kress og van Leeuwen (2006, s. 121) finnes kart og diagram vanligvis i kontekster som tilbyr høyt vurdert kunnskap, frigjort fra subjektiv involvering. Klimasonekartet (figur 3) er distansert og upersonlig - kartet viser hele verden. Tekstuttrykket er abstrahert, med utvalgte farger og minimal bakgrunn. Dette er vitenskapelig modalitet: Kartet skal vise jordas klimasonemønster. Bare essensielle egenskaper er med. Fargevalget, fra en begrenset palett, skiller klimatyper fra hverandre. For mye detaljer og ikonisk likhet ville distrahert fra den analytiske hensikten. Vi kan si at tekstskaperne tilbyr et analytisk perspektiv tilgjengeliggjort gjennom geografifaglige konvensjoner.

Det krever aktivt arbeid å gå inn i en slik tekst. Klimasonekartet er trykket i atlas for ungdomsskolen, men ingenting i kartet tilrettelegger didaktisk for en novise. Hvordan læreren legger til rette for at elevene skal gå i interaksjon med teksten, blir derfor avgjørende. Læreren ber elevene forenkle klimasonekartet slik at det ligner figur 1 . Dette er en kompleks oppgave. I figur 1 er det klimasonene, som elevene har kjennskap til, som uttrykkes med farger. I figur 3 er det de ukjente klimatypene. Elevene må altså koble fargene til klimatyper og klimatypene til klimasoner før de fargelegger. De må aktivt inn i kartet for å sortere. Intensjonen om å forenkle til fire hovedkategorier blir ikke klart uttrykt idet læreren sier: «dere skal tegne det her av (...) Fint og så presist som dere kan». Måten læreren gir oppgaven på, vektlegger organiseringen mer enn presis forklaring av oppdraget, og den inneholder ingen eksplisitt leseforståelsesinstruksjon (Biancarosa \& Snow, 2006).

Læreren avdekker raskt at elevene har vansker med å tolke og overføre til et forenklet uttrykk. Til enkeltelever tilbyr han en ny interaksjon med både modellering og reflekterende spørsmål. For Martin og Jakob tydeliggjør han (a) at det finnes koder til kartet, (b) hvordan kodene kan kobles til kartet, (c) at poenget i oppgaven var å få fram de fire hovedsonene og (d) at disse er uttrykt med tverrgående streker. Begge guttene går fra å bruke fargene til å bruke strekene for å skille sonene, en strategi som stemmer bedre med tekstuttrykkets representasjon, komposisjon og interaksjon. Denne nye interaksjonen handler likevel om tekstbruk innenfor klasserommet. Det helt overordnede blikket, at klimasonekartet har denne strukturen fordi det skal framstille klimamønster analytisk (representasjon), og at denne analytiske strukturen med sin vitenskapelige modalitet har en klar funksjon i geografi (interaksjon), vies ikke oppmerksomhet. 


\section{Eksempel 2: Hvordan legger lærer til rette for lesing av klimadiagram?}

Læreren ønsker at elevene skal kunne lese klimadiagram, en ny tekstform for dem: «Nå skal vi se på et klimadiagram. I løpet av timen håper jeg dere skal bli i stand til å tolke de og si noe om plassen ut fra diagrammet.» Bak ham, på lerretet, vises følgende:
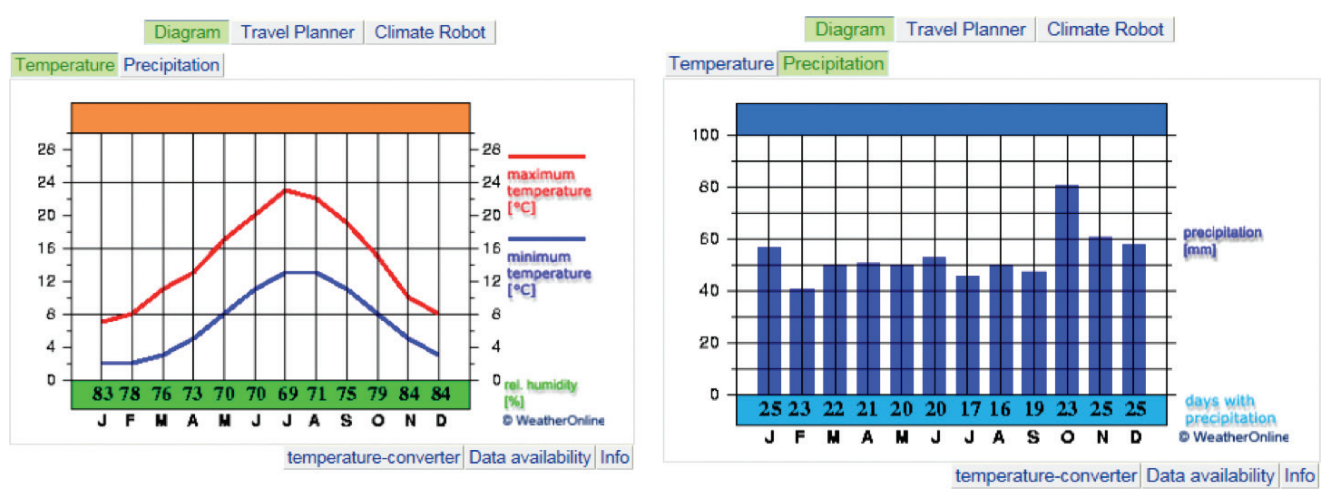

Figur 6. Klimadiagram fra weatheronline.co.uk av foreløpig ukjent sted

Læreren peker på grafen til venstre, leser y-aksens tall og forklarer at de viser temperatur. Han peker på x-aksens bokstaver: «Hva er dette da?» En elev foreslår måneder. "Riktig», sier læreren: "Hva tror dere den røde og den blå streken er?" En elev foreslår "varmt og kaldt». Læreren bekrefter, men gir ordet til en annen elev som svarer: "Gjennomsnitt høyest og lavest temperatur.» Læreren nikker: «I de enkelte månedene». Han går til søylediagrammet. "Her borte er det nedbør. Nedbørsmengde.» Han peker på y-aksen og leser: «0-20-40-60-80-100. Og dette angir hvor mange millimeter nedbør det er per måned.» Han peker videre på tallene nederst på søylediagrammet og spør hva elevene tror de er. Når ingen forslag kommer, hinter han: "Hvor mange dager er det i en måned?» En hånd spretter opp: «30 og 31.» Læreren bekrefter: «Dette tallet angir hvor mange regnversdager det er."

Under diagrammene står fire oppgaver og en nedbørsreferanse:

Analyseoppgave:
1. Beskriv hvordan temperaturen er i løpet av året. Varmt? Kaldt?
2. Beskriv hvordan nedbøren er i løpet av året. Mye? Lite?
3. Ser det ut som om stedet har tydelige årstider?
4. Hvilken klimasone kan dette passe til?

\begin{tabular}{l}
\hline Nedbørsreferanse: \\
I Sandnes regner det ca. \\
$140 \mathrm{~mm}$ i september.
\end{tabular}

Figur 7. Analyseoppgaver som støtter utforskningen av klimadiagrammene

Læreren sammenligner nedbørsreferansen med diagrammet. Han finner september, følger søylen opp og bort til y-aksen. Deretter ber han elevene "gå gjennom listen og til slutt oppgave fire: Hvilken klimasone er dette? Gå muntlig gjennom punktene. Beskriv klimadiagrammene. Hvordan ser de ut?» Elevene går i gang. 
Utsagn høres: «Her er jo ganske variert», «det er tydelige årstider», «dette er den varmeste måneden». En lurer på hvordan han kan beskrive klimaet når det varierer fra måned til måned. En annen observerer at det kaldeste fremdeles er over null grader og bruker diagrammet til å reflektere over faktaene. Læreren hjelper enkeltelever ved å spørre: Er det varmt? Kaldt? Når er det kaldest? Er det veldig kaldt da?

Læreren samler klassen. Han peker der den blå streken starter: «Dette er den kaldeste snittemperaturen i løpet av januar», og flytter hånda til den røde: «og den varmeste, altså snittet av de varmeste målingene hver dag i januar.» Uten å ta pekefingeren fra den røde streken, setter han tommelen på den blå: «Så det er avstanden på, den gjennomsnittlige avstanden på, dag og natt, stort sett. I januar.»

Lærer: Grafen starter på null. Så hvordan kan vi beskrive temperaturen på denne plassen her? Ida?

Ida: Det er kaldt, men ikke sånn veldig mange minusgrader.

Lærer: Nei?

Ida: Det er liksom ikke, det kunne vært Norge, men der er det som regel noen minusgrader en eller annen dag.

Lærer: Ja. Så du tenker dette er, hvor er det i forhold til Norge tror du da?

Ida: Jeg tror det er litt lenger sør.

Lærer: Litt lenger sør enn Norge. Hvorfor tenker du at det kunne ha vært Norge?

Ida: Eh, fordi at, eh, bortsett fra det med minusgradene, så er temperaturen ganske lik som i Norge.

Lærer: Ja. (peker på søylediagrammet) Dette, hvordan er det i forhold til Norge da, tror dere? Nedbøren. Stian?

Stian: En del mindre siden det står at i Sandnes regner det ca 140 millimeter i september og der regner det ... jo ... bittelitt mer enn 40 .

Lærer: Ja, stemmer.

Stian: Så da blir det mye mindre. Hvertfall på den måneden.

Lærer: Ja. September er og en av de månedene med mest regn i Norge, eller i Sandnes. September, oktober. Men ja, litt mindre, stemmer. Er det tydelige årstider her? Kaja?

Kaja: Ja, fordi at det er jo kaldt i januar og så blir det varmere og varmere til august og så går det ned igjen.

Lærer: Ja. At grafen går opp i en spiss sånn som dette (følger streken med fingrene) er et tegn på tydelige årstider fordi det er merkbart varmere her på sommeren enn det er på vinteren. 
Klassen diskuterer hvilken form nedbøren kommer i, hvilken sone de tror stedet ligger i, og om de kunne tenke seg å bo der. Læreren avslører: «Det er London».

Elevene får utdelt ark med seks klimapar. Figur 8 gjengir to av dem. Igjen skal elevene identifisere hvilken klimasone diagrammene representerer gjennom de fire spørsmålene.

Flere trenger ny forklaring på at strekene er gjennomsnittet av de varmeste og kaldeste målingene hver dag. Læreren følger streken med fingrene: «Her ser du hvordan det endrer seg gjennom året. Nesten alltid er blå natt og rød dag.»

Elevene har stort engasjement til tross for at det er sent i timen. De diskuterer valg og sammenligner svar. Strategiene varierer. Martin, Jakob og Kari diskuterer om diagram E er i polar eller temperert sone. Diagrammet viser Anchorage i Alaska, på grensen mellom sonene. Jakob tror det må være i polarsonen. Martin protesterer og peker på et trekk som ikke passer til det han vet om polarsonen: «Njaaa ... Det er jo drøyt med regn, og det kan ikke være så mye regn i en polarsone.» Kari påpeker at nedbør "trenger ikke være regn». Martin studerer diagrammet: «Minus 12 grader, kan det være i Norge? Det kan og være opp imot 20 grader. Plussgrader.» Kaja sammenligner det visuelle uttrykket med de andre: «De der to var jo litt like, hvert fall på sånn varme strøk. Der er litt mer regn.» Jakob spør om ikke diagram F også er temperert, og blir enig med Kaja om at det «bør jo være minst én polarsone». Timen avsluttes med felles gjennomgang av hva elevene har funnet ut. Elevene må begrunne svarene ved å beskrive klimaet.

D

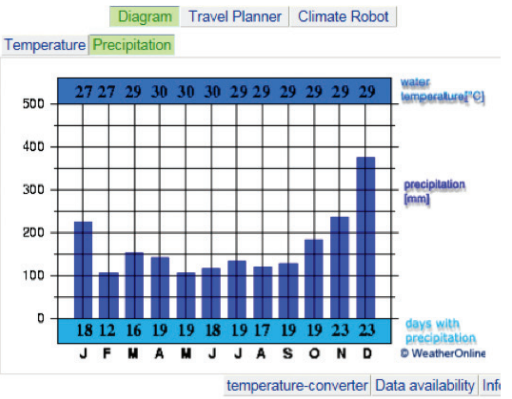

$\mathrm{E}$

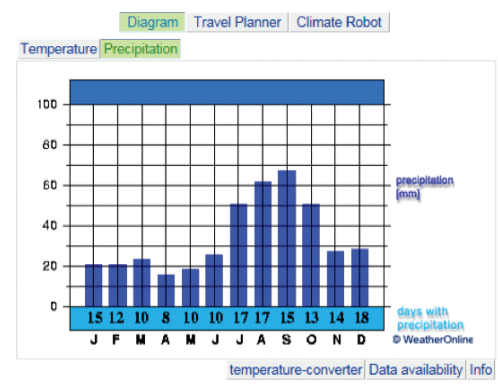

Diagram Travel Planner Climate Robot

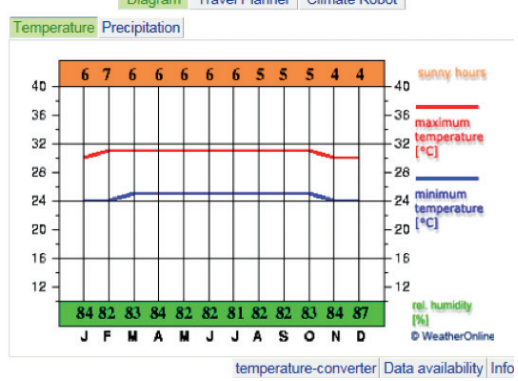

Diagram Travel Planner Climate Robot

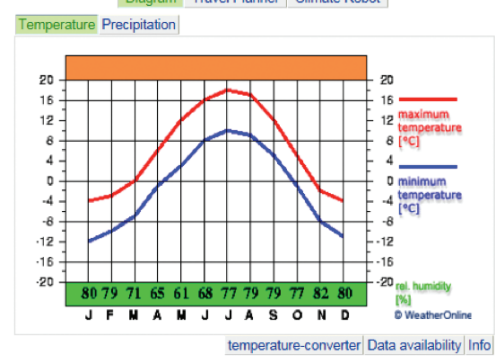

Figur 8. To av de seks ukjente klimadiagrammene fra weatheronline.co.uk som elevene fikk utdelt. 
Her ser vi at elevene forstår og utnytter tekstens oppbygging i større grad enn i eksempel 1, Martin ved å se til detaljer, og Kaja og Jakob ved å sammenligne det helhetlige, visuelle uttrykket med de andre på arket. Hvordan har læreren tilrettelagt for lesing av klimadiagram?

\section{Representasjon}

Klimadiagrammet viser ett steds gjennomsnittsvær ut fra årlig temperatur- og nedbørsvariasjon, og kan plasseres som en narrativ representasjon. Klimadiagrammet kan leses både som konkret narrativ om hvordan temperatur og nedbør endrer seg fra måned til måned, og som et helhetlig bilde av klimaet på det bestemte stedet. At diagram presenterer prosesser som romlige konfigurasjoner, sammenligner Kress og van Leeuwen (2006, s. 62) med nominaliseringer. Nominaliseringer, for eksempel 'temperaturendring' og 'nedbørsvariasjon', omgjør observerbare prosesser til klassifiserbare ting, noe som får Wignell, Martin \& Eggins (1989) og van Leeuwen \& Humphrey (1996) til å plassere dem sentralt i den geografiske diskursen. På lignende vis har klimadiagrammet et komprimert og informasjonstett tekstuttrykk. I begge tilfeller må informasjonen pakkes ut for å få tak i prosessen.

I kontrasten som søylene og vektorenes sterke farger gir mot rutenettene, framstår et mønster hvor vi kan se utviklingen av temperatur og nedbør gjennom året. Narrativen er således framtredende i tekstuttrykket. Vektorene og søylene må likevel kobles til informasjonen i x- og y-aksen for å gi spesifikk mening. I figur 7 ser vi to visuelt ulike narrativer. Temperaturforskjellen ses med ett blikk: Diagram D viser stabil temperatur hele året, mens diagram E har tydelig kurve fra kaldt til varmt til kaldt igjen. Ser en derimot for fort på nedbørsdiagrammet, kan nedbørsmengden se omtrent lik ut. Først ved sammenligning av skalaene kommer den store forskjellen fram: I diagram E er måneden med mest nedbør under $70 \mathrm{~mm}$, i diagram $\mathrm{D}$ har alle over $100 \mathrm{~mm}$.

Læreren viser flere ganger til narrativen ved å eksplisitt peke på vektoren. Han forklarer hvordan elevene kan se værendringen ved å følge strekene, og hvordan tydelige årstider representeres med en spiss graf. Han viser hvordan den blå og røde streken kan samleses ved fysisk å markere avstanden mellom dem, og han gir vektorene en ny nyanse når han forklarer at blå er natt og rød dag. Læreren gir altså eksplisitt leseforståelsesinstruksjon ved å modellere lesing av tekstene (jf. Biancarosa \& Snow, 2006) og hvordan lesingen avdekker geografifaglige mønstre som temperatur og nedbør (Johnson et al., 2011).

\section{Komposisjon}

Klimadiagrammene er todelte: Mens grafen viser gjennomsnittstemperaturene hver dag, viser søylediagrammet gjennomsnittet av nedbørsmengden per måned. En tynn strek rammer inn og separerer diagrammene. At diagrammene er visuelt like, tyder likevel på at de hører sammen. Hva y-aksene representerer, forklares av læreren før han ber om forslag på x-aksen samt den røde og blå streken. Dette 
er neppe tilfeldig ettersom y-aksen inneholder diagrammenes spesifikke mening, grader $\mathrm{i}$ celsius og nedbør i millimeter, mens begge $\mathrm{x}$-aksene viser årets tolv måneder. I den korte gjennomgangen både peker og forklarer læreren delene i diagrammene samt hvordan diagrammet for temperatur og for nedbør samleses. Slik modellerer læreren en prototype og viser eksplisitt hvilke element elevene bør legge merke til (jf. Gee, 2002).

Læreren modellerer ikke hele tekstuttrykket med en gang, men lar elevene prøve seg på tolkninger med støtte i de fire oppgavene (Figur 7). Før de går i gang, viser han hvordan de bruker nedbørsreferansen sammen med diagrammet. Slik modellerer han også hvordan elevene kan løse oppgavene. I oppgavegjennomgangen kommer elevene med sine første tolkninger av klimadiagrammene. Ida observerer at "det er kaldt, men ikke sånn veldig mange minusgrader», sammenligner med Norge og konkluderer med at det må være litt lenger sør. Stian sammenligner nedbøren med referansetallet, og Kaja forklarer at stedet har årstider. Elevene forholder seg til teksten, bruker lærerens modellerte lesing og kobler informasjonen til egne erfaringer med vær og vind, slik også geografen i Johnson et al. (2011) sammenstilte nye data med brede basiskunnskaper når hun skulle identifisere mønstre. Komposisjonen blir altså eksplisitt gjennomgått flere ganger med stigende selvstendighetsgrad. Både mens elevene jobber og i oppgavegjennomgangen, støtter læreren elevene gjennom spørsmål som tvinger dem til å koble graf og søyler til skalaene og således se hvordan komposisjonen viser mønstre som er sentrale for å plassere stedet i klimasoner.

\section{Interaksjon}

Læreren har hentet diagrammene fra weatheronline.co.uk. Iscenesettingen i klasserommet blir viktig fordi det er her tekstuttrykket tilpasses elevmottakerne. Vi har sett hvordan læreren forklarer tekstdelene og eksplisitt viser hvordan en både kan lese et punkt fra diagrammet og følge hele utviklingen langs vektoren. Læreren gir også elevene mulighet til å simulere lesemåten med støtte i oppgavene (jf. Gee, 2002). Oppgavene krever at elevene må kunne lese grafen, men oppgavedesignet er sterkt strukturert. Gjennom oppgave 1 og 2 skal elevene se mønstre i temperatur og nedbør ved å legge merke til om det er varmt eller kaldt, mye eller lite nedbør. Oppgave 3 ber dem sette mønstrene sammen til et overordnet mønster om årstider. I oppgave 4 skal elevene tolke mønstrene i lys av kunnskapen de har om de fire klimasonene. At elevene blir bedt om å beskrive temperatur og nedbør før de tolker det samla uttrykket, er interessant. De får konsentrere seg om en og en detalj før de må sette dem sammen. Mens de øver på nye ferdigheter får de mye støtte, som gradvis reduseres (jf. Biancarosa \& Snow, 2006). Oppgavene ber dessuten elevene oversette et visuelt uttrykk til verbalspråk og tvinger dem således til å forholde seg tett til teksten, noe som er i tråd med funn om å la elevene diskutere tekst og ikke bare innhold (Biancarosa \& Snow, 2006). Ifølge Johnson et al. (2011) handler geografi om å beskrive, se og tolke mønstre. Det elevene blir bedt 
om å beskrive og tolke, er selve narrativen i representasjonen: hvordan temperatur og nedbør utvikler seg i løpet av året. Fra et geografifaglig perspektiv er det en relevant oppgave.

En annen interessant faktor er lærerens spørsmålsstilling. Innledningsvis, når læreren modellerer felles eksempel, dreier spørsmålene seg om å legge merke til det vesentlige. Læreren peker på detaljer i diagrammet og spør: «Hva er dette, da?» Spørsmålene fungerer som stillas for å lese selve tekstuttrykket. Når elevene har begynt å tolke diagrammene, endres spørsmålene til å be dem begrunne tolkningene: «Hvordan landet du på den?» eller reflektere: «Hvorfor tenker du at det kunne vært Norge?» At spørsmålene inviterer elevene til å tolke og reflektere over mønstre, er i tråd med epistemologien i geografifaget (Johnson et al., 2011), og kan også stå som den subjektive involveringen Kress og van Leeuwen (2006, s. 121) mener mangler i tekstuttrykk med vitenskapelig modalitet. Heller ikke i dette eksempelet finner vi et overordnet perspektiv om hvilken funksjon et klimadiagram har utenfor klasserommet.

\section{Hvordan kan lærere legge til rette for lesing av grafiske representasjoner i geografi?}

Innledningsvis så vi Løvland (2011) peke på underutnytting av læringspotensialet i multimodale tekster fordi elever ikke bruker tjenlige lesestrategier og lærere ikke designer aktiviteter som benytter multimodaliteten. Dette ser vi også i eksempel 1; representasjonene kan ikke ganske enkelt gis elevene. Utfordringene elevene har i møte med klimasonekartet, handler både om tekstoppbygging og fag, og det er mitt syn at faglige, tekstlige og pedagogiske utfordringer må ses i sammenheng. Hva kan vi så lære av læreren i denne case-studien?

\section{Samlesing og deiktisk modellering}

Tar vi utgangspunkt i hva Johnson et al. (2011) skisserer som geografisk tekstpraksis, trenger elevene lesestrategier som hjelper dem å sammenstille element, identifisere mønstre og tolke disse ut fra ulike kilder, også fra basiskunnskaper om verden. I tillegg trenger de lesestrategier tilpasset de grafiske tekstutfordringene. I begge eksemplene ser vi at samlesing av tekstdeler er viktig: av kart og koder i eksempel 1, og av rød og blå vektor samt temperatur og nedbør i eksempel 2. Måten læreren tilrettelegger for samlesing, kan vi kalle deiktisk modellering. Både i plenum og med enkeltelever pakker han opp tekstuttrykket ved å peke på sentrale detaljer og eksplisitt vise sammenhengen mellom tekstdelene. I eksempel 1 peker han ut sammenhengen mellom fargekodene, fargene i kartet og guttenes seleksjon. I eksempel 2 følger han vektoren med fingrene og viser avstanden i temperatur mellom natt og dag med pekefinger og tommel. Utpekingen kan stå som en geografispesifikk måte å gi eksplisitt leseforståelsesinstruksjon i kompakte visuelle tekstuttrykk. Det synes viktig å knytte denne deiktiske modelleringen til tekstenes representasjon. 


\section{Oppgavedesign som utforsker fagets tekster}

Oppgavene elevene får, er også viktige for tekstbruken deres. Mens elevsamtalene handler om fargevalg i eksempel 1, utforsker de diagrammene i eksempel 2. Oppgaven i eksempel 2 er mer utforskende enn repetisjonsoppgaven i 1, noe som i seg selv sannsynligvis styrker elevengasjementet. Men det sterkt strukturerte oppgavedesignet, knyttet direkte til tekstene, gir også elevene problemstillinger som er konkrete nok til å kunne diskuteres og løses sammen. Å la elevene samhandle om teksters form og funksjon, ikke bare innhold, understrekes hos Biancarosa og Snow (2006). Det er påfallende at kartaktiviteten var tenkt som en kjapp repetisjon, mens læreren har dedikert en hel time med grundige stillas for å lære elevene å lese klimadiagrammet. Kanskje vurderes det visuelle og ikoniske kartet som enklere enn et mer numerisk klimadiagram, eller kanskje er kompleksiteten usynlig for en som er kompetent i faget?

$\AA$ forenkle kartet krever at elevene identifiserer klimasonemønsteret. Fellesundervisningen i starten av begge eksemplene viser at læreren selv er dyktig til å identifisere og visualisere geografiske sammenhenger (jf. Johnson et al., 2011). Evnen overføres ikke uten videre til elevene, trass grundig tavlegjennomgang. At overføring av fagkunnskap er sterkt vektlagt, også i norske klasserom, og at kunnskapen ofte framstilles som udiskuterbar fakta (Blikstad-Balas, 2013; Skjelbred, 2006), kaller Wade \& Moje (2000) for overføringsmodellen. Eksempelvis forteller læreren at jordkloden deles inn i fire klimasoner. Dette er en vanlig fremstilling, men ikke den eneste, noe vi ser av figur 1 , som representerer fem klimasoner. I overføringsmodellen figurerer tekster som bærere og kontrollører av kunnskap. Kunnskap tilegnet slik overføres ikke like lett til nye situasjoner, og prestasjoner svekkes når elevene skal relatere ny kunnskap til forkunnskap (Goldman, 1997). Mens vi ser mange eksempler på at elevene bruker forkunnskaper til å utforske klimadiagrammene, finner vi ingen slike eksempler når de jobber med kartet. Johnson et al. (2011) nevner utforskende spørsmål som det som driver faget videre. Oppgaver som bruker fagets tekster som verktøy for å lære og for å konstruere ny kunnskap, kan således stå som en viktig tekstpraksis i geografi til å lære elevene opp i en faglig relevant kompetanse.

\section{Reflekterende spørsmål om faget}

Læreren er dyktig til å stille reflekterende spørsmål som avdekker og legger til rette for å tolke mønstre. Spørsmålsstillingen samsvarer med tankesettet i faget (jf. Johnson et al., 2011). Den avdekker også hva elevene ikke forstår, noe som hjelper han å hjelpe elevene, og kan stå som tilnærmingen Kress og van Leeuwen (2006) mener mangler i vitenskapelige kontekster. I begge eksemplene driver lærerens reflekterende spørsmål elevenes tekstforståelse framover.

Likeledes kunne reflekterende spørsmål blitt brukt til å utforske hvordan tekstene henger sammen med geografifagets diskurs. I begge timene får elevene tilgang til sentrale geografifaglige ressurser og til lærerens lese- og tenkemåter. At de er i tråd med faglige lese- og tenkemåter, gjøres derimot ikke eksplisitt. Det helt overordnede 
blikket på at disse grafiske representasjonene er gode til å uttrykke mønster og prosesser, og at det å beskrive mønster og prosesser er sentralt i geografi, finner vi ikke. Det er muligens mye å forvente $i$ et delemne $i$ et lite fag på åttende trinn, og det er verdt å minne om at de to eksemplene er tidlige utdrag i et omfattende emne der intensjonen var å legge grunnlaget for resten av emnet ved å gi tilgang til tekstuttrykkene. Likevel, Biancarosa og Snow (2006) viser til god læringseffekt av å bruke strategier i flere kontekster, ulike fagområder og sjangre. Elevene i denne studien identifiserer mønstre $\mathrm{i}$ to sjangre. Således kunne tekstene, hadde de blitt sett i relieff av hverandre, av lærers reflekterende spørsmål eller av elevene i utforskende oppgaver, gitt et nyttig metablikk på hvordan ideer, kunnskap og begrep er konstruert og mediert i faget (jf. fagspesifikk literacy). Dette kunne muligens videre gitt potensial for å produsere faglige ytringer (jf. Gee, 2002).

\section{Små fag har også viktige bidrag til den helhetlige leseopplæringen}

Tekstbruk avhenger av situasjon og kulturell forankring, og slik grafiske representasjoner i geografi er en spesifikk form for grafiske representasjoner, er også ungdomsskolefaget en spesifikk form for geografi. Tekstene elevene har møtt i denne studien har en bestemt geografifaglig funksjon de sannsynligvis ikke kjenner fra andre fag. Elevene kan også ha bruk for klimasonekart og klimadiagram utenfor skolen, som når de leser debattinnlegg om klimaendringer eller vil sjekke når på året det er best å reise til et bestemt sted. Små fag, som grunnskolegeografi, har med andre ord viktige bidrag til den helhetlige leseopplæringen.

\section{Litteraturliste}

Alexander, P. A. (2003). The Development of Expertise: The Journey from Acclimation to Proficiency. Educational Researcher, 32(8), 10-14.

Barton, D., \& Hamilton, M. (1998). Local Literacies: Reading andWriting in One Community. London: Routledge. Biancarosa, G., \& Snow, C. (2006). Reading Next - A Vision for Action and Research in Middle and High School Literacy: A report to Carnegie Corporation of New York (2. utg.). Washington, DC: Alliance for Excellent Education.

Blikstad-Balas, M. (2013). Redefining School Literacy: Prominent literacy practices across subjects in upper secondary school. (Doktoravhandling). University of Oslo.

Eikli, E. (2013). Norwegian school geography and geographical education: A new research field? Norsk Geografisk Tidsskrift - Norwegian fournal of Geography, 67(3), 128-134. https://doi.org/10.1080/00291951. 2013.809383

Flyvbjerg, B. (1991). Rationalitet og magt. Bind 1. Det konkretes videnkap. Odense: Akademisk Forlag.

Gee, J. P. (2002). Learning in Semiotic Domains: A Social and Situated Account. I B. M. \& J. H. D. Schalert, C. Fairbanks, J. Worthy (red.), The 51st Yearbook of the National Reading Conference. (s. 23-31). Oak Creek: University Press.

Goldman, S. R. (1997). Learning from text: Reflections on the past and suggestions for the future. Discourse Processes, 23(3), 357-398.

Gourvennec, A. F. (2016). Litteraturfaglig praksis: Avgangselevers retrospektive blikk på arbeid med litterære tekster i videregående skole. Nordic fournal of Literacy Research, 2, 1-18. https://doi.org/10.17585/njlr. v2i1.271

Heath, S. B. (1983). Ways with Words : Language, Life, and Work in Communities and Classrooms. Cambridge: Cambridge University Press. 
Hoel, T., \& Håland, A. (2016). Leseopplæring i norskfagets begynneropplæring med fokus på fagspesifikk lesekompetanse. Nordic fournal of Literacy Research, 2, 21-36. https://doi.org/10.17585/njlr.v2i1.195

Hoem, T. F., \& Staurseth, H. E. (2014). Lesing i samfunnsfag. I. A. Skaftun, O. J. Solheim, \& P. H. Uppstad, (red.), Leseboka: Leseopplcering $i$ alle fag på ungdomstrinnet. (s. 145-165). Oslo.

Johnson, H., Watson, P. A., Delahunty, T., McSwiggen, P., \& Smith, T. (2011). What It Is They Do: Differentiating Knowledge and Literacy Practices Across Content Disciplines. Fournal of Adolescent and Adult Literacy, 55(2), 100-109. https://doi.org/10.1002/JAAL.00013

Kleve, B., \& Penne, S. (2012). Norsk og matematikk i et literacy-perspektiv: Metabevissthet også for de svake elevene. Acta Didactica Norge, 6(1), 1-18.

Knain, E. (2014). Scientific Literacy for Participation: A Systemic Functional Approach to Analysis of School Science Discourses. Rotterdam: Sense Publishers.

Kress, G., \& van Leeuwen, T. (2006). Reading Images:The Grammar ofVisual Design (2. utg.). London: Routledge. Løvland, A. (2011). På jakt etter svar og forståing: Samansette fagtekstar $i$ skulen. Bergen: Fagbokforlaget/LNU.

Mikkelsen, R. (red.). (2006). Cappelens atlas ungdomstrinnet. Oslo: Cappelen Damm.

Moje, E. B. (2015). Doing and teaching disciplinary literacy with adolescent learners. Harvard Educational Review, 85(2). https://doi.org/10.1007/BF02770787

Pearson, D. P., Moje, E. B., \& Greenleaf, C. (2010). Literacy and Science: Each in the Service of the Other. Science, 328 (April), 459-464.

Rainey, E. C. (2017). Disciplinary Literacy in English Language Arts: Exploring the Social and Problem-Based Nature of Literary Reading and Reasoning. Reading Research Quarterly, 52(1), 53-71. https://doi. org/10.1002/rrq. 154

Reisman, A. (2012). Reading Like a Historian: A Document-Based History Curriculum Intervention in Urban High Schools. Cognition and Instruction, 30(1), 86-112. https://doi.org/10.1080/07370008.2011.634081

Schleppegrell, M. J. (2004). The Language of Schooling: A Functional Linguistics Perspective. Mahwah, NJ: Lawrence Erlbaum.

Scribner, S., \& Cole, M. (1973). Cognitive Consequences of Formal and Informal Education. Science, 182(4112), 553-559. https://doi.org/10.1126/science.182.4112.553

Shanahan, C., Shanahan, T., \& Misischia, C. (2011). Analysis of Expert Readers in Three Disciplines: History, Mathematics, and Chemistry. Fournal of Literacy Research, 43(4), 393-429.

Skaftun, A., Solheim, O. J., \& Uppstad, P. H. (red.). (2014). Leseboka : leseopplcering $i$ alle fag på ungdomstrinnet. Oslo: Cappelen Damm akademisk.

Skjelbred, D. (2006). Sjangrer og lesemåter i fagtekster. I E. Maagerø \& E. S. Tønnessen (red.), Å lese $i$ alle fag. Oslo: Universitetsforlaget.

Skjelbred, D., \& Aamotsbakken, B. (red.). (2010). Lesing av fagtekster som grunnleggende ferdighet. Oslo: Novus forlag.

Street, B. V. (1984). Literacy in theory and practice (Bd. 9). Cambridge: Cambridge University Press.

Säljö, R. (2010). Digital tools and challenges to institutional traditions of learning: technologies, social memory and the performative nature of learning. Fournal of Computer Assisted Learning, 26(1), 53-64. https://doi. org/10.1126/science. 182.4112 .553

Sørvik, G. O., \& Mork, S. M. (2015). Scientific literacy as social practice: Implications for reading and writing in science classrooms. Nordic Studies in Science Education, 11(3), 268-281.

Traavik, H., Hallås, O., \& Ørvig, A. (red.). (2009). Grunnleggende ferdigheter $i$ alle fag. Oslo: Universitetsforl.

Utdanningsdirektoratet. (2013) Læreplan i samfunnsfag. Oslo.

van Leeuwen, T., \& Humphrey, S. (1996). On Learning to Look through a Geographer's Eyes. I R. Hasan \& G. Williams (red.), Literacy in Society (Applied Linguistics and Lanugage Study). (s. 29-49). London: Longman.

Wade, S. E., \& Moje, E. B. (2000). The Role of Text in Classroom Learning. I M. L. Kamil, P. B. Mosenthal, P. D. Pearson \& R. Barr (red.), Handbook of Reading Research. (s. 609-627). Abingdon: Routledge Handbooks Online. https://doi.org/10.1126/science.182.4112.553

Wignell, P., Martin, J. R., \& Eggins, S. (1989). The Discourse of Geography: Ordering and Explaining the Experiential World. Linguistics and Education, 1(4), 359-391. https://doi.org/10.1016/ S0898-5898(89)80007-5

Wineburg, S. (2001). Historical Thinking and Other Unnatural Acts: Charting the Future of Teaching the Past. Philadelphia: Temple University Press. https://doi.org/10.1016/S0898-5898(89)80007-5 